\title{
Characterization of soil nutrient management and post-harvest handling practices for onion production in the central rift valley region of Ethiopia
}

\author{
Negasi Tekeste A. ${ }^{1,}$, , Nigussie Dechassa R. $^{2}$, Kebede Woldetsadik ${ }^{2}$, Lemma Dessalegne ${ }^{3}$, \\ Abuhay Takele ${ }^{3}$ \\ ${ }^{1}$ Aksum University, College of Agriculture, P O Box 314, Shire, Ethiopia \\ ${ }^{2}$ Department of Plant Sciences, Haramaya University, P O Box 138, Dire-Dawa, Ethiopia \\ ${ }^{3}$ Melkassa Agricultural Research Centre, P O Box 2500, Adama, Ethiopia
}

\section{Email address:}

negasite@gmail.com(N. Tekeste A.), nigussiedachassa@gmail.com(N. Dechassa R.), Tsadike@haramaya.edu.et(K. Woldetsadik), lemmades@yahoo.com(L. Dessalegn),kidumet94@gmail.com(A. Takele)

\section{To cite this article:}

Negasi Tekeste A., Nigussie Dechassa R., Kebede Woldetsadik, Lemma Dessalegne, Abuhay Takele. Characterization of Soil Nutrient Management and Post-harvest Handling Practices for Onion Production in the Central Rift Valley Region of Ethiopia. Agriculture, Forestry and Fisheries. Vol. 2, No. 5, 2013, pp. 184-195. doi: 10.11648/j.aff.20130205.12

\begin{abstract}
Onion is an important cash crop for smallholder farmers in the Central Rift Valley Region of Ethiopia. A survey was conducted during the off-season of 2011 to document nutrient management and post-harvest handling practices in onion production in four districts (Adama, Merti, Dugda Bora and Adamitulu-Jiddokombolcha) in the region. Data were collected from 128 farmers using a standard questionnaire and focus group discussions. The results revealed that all of the sampled smallholder onion growing farmers used Diammonium phosphate (DAP) and urea whilst only $10.9 \%$ and $5.5 \%$ used farmyard manure (FYM) and compost, respectively. The growers on average used $298.8 \mathrm{~kg} \mathrm{ha}^{-1}$ Urea and $299.21 \mathrm{~kg}^{\mathrm{DAP}} \mathrm{ha}^{-1}$. Only small amounts of farmyard manure $\left(1.71 \mathrm{tha}^{-1}\right)$ and compost $\left(1.56 \mathrm{tha}^{-1}\right)$ were applied by the onion growers. The data also showed that farmers did not practise curing and storing of onion bulbs, and sold the produce on the field during harvest at farm-gate prices. In conclusion, the results of the study revealed that farmers in the region produce onions with application of higher rates of inorganic mineral NP fertilizers than the rates commonly recommended by the research system. The results also showed that the farmers did not subject harvested onion bulbs to any post-harvest management practices for enhancing shelf-life and marketability of the crop.
\end{abstract}

Keywords: Inorganic Fertilizers, Farmyard Manure, Organic Fertilizer, Soil Fertility Management

\section{Introduction}

Onion (Allium cepa L. var. cepa) is an important vegetable crop worldwide, and is ranked second among all vegetables in economic importance [1]. In Ethiopia, the crop is one of the most important vegetables produced by smallholder farmers mainly as a source of cash income and for flavouring the local stew 'wot' [2,3]. In Ethiopia, the crop is believed to be more intensively consumed than any other vegetable crop. A lion's share of $95 \%$ of the vegetables and fruits produced in the country comes from the smallholder sector [4].

The Ethiopian Central Rift Valley region is an area of great economic importance to the national food security and foreign exchange earnings of the country through production of export crops [4]. However, the region is highly affected by land degradation mainly due to the rapidly growing population and lack of proper soil fertility management practices [5]. The bulk of onion produced in the county comes from this region where cultivation is mainly carried out using irrigation [6, 7]. However, the average productivity of onion is low and, at present, the national average yield is as low as $10.75 \mathrm{tha}^{-1}[8]$ as compared to the world's average yield of $17.30 \mathrm{t} \mathrm{ha}^{-1}$ [9]. Many reports indicate that, in Ethiopia, and in the rift valley areas, the low productivity of vegetables including onions, among others, is attributed to low or depleting soil fertility, poor agronomic practices such as imbalanced fertilization and lack of proper postharvest handling [2,3]. Moreover, postharvest losses in the country account for about $10.7 \%$ and $30 \%$ for onions and other vegetables, respectively $[10,3]$. In fact, horticultural 
crop producers in developing countries are mostly resource-poor smallholder farmers who lack resources, and they are rarely organized into formal cooperatives or associations to tackle production and postharvest related problems $[11,12]$.

Appropriate use of pre-harvest practices can reduce losses of horticultural crops and enhance farming sustainability [13]. Proper soil fertility management practices may alleviate the declining soil fertility and improve crop yield and quality [14]. In onion production, timing, rate, and type of fertilizer application have been reported to have effects on yield, quality, as well as postharvest shelf-life of the crop [15, 16]. The reports further indicated that with proper nutrient management, there is a possibility of extending onion shelf-life for a considerable period of time under ambient conditions. This may create lucrative marketing opportunities for farmers if they get the option of storing their produces when there is an oversupply of onion bulbs in the market and prices fall.

Profitable onion production requires appropriate soil fertility and post-harvest management as well as addressing other production constraints. However, little research has been done in Ethiopia to appraise soil nutrient management and postharvest handling practices in onion production. Results of such studies could be an impetus to design and formulate optimal fertilizer requirements for higher productivity and enhanced shelf-life of the crop. Therefore, there is a need to test the hypothesis that smallholder farmers in the Rift Valley Region of Ethiopia practise appropriate soil fertility and postharvest management in onion production.

It is, thus, vital to characterize nutrient and postharvest management practices of smallholder farmers producing onions in the region. Documenting the available information will enable stakeholders to be aware of the prevailing conditions and constraints of production for appropriate interventions to improve productivity and profitability of the crop. This paper presents the results of a study conducted to characterize soil nutrient and post-harvest handling practices in onion production in the Central Rift Valley Region of Ethiopia.

\section{Materials and Methods}

\subsection{Description of the Study Area}

The study was undertaken in the Central Rift Valley Region of Ethiopia, which is located between longitude $38^{\circ} 00^{\prime}-39^{\circ} 30^{\prime} \mathrm{E}$ and latitude $7^{\circ} 00^{\prime}-8^{\circ} 30^{\prime} \mathrm{N}$ latitude and at altitude ranging between 1200 - 1640 metres above sea level. The area has an arid to semi-arid climate with mean maximum and minimum temperatures of $28.5{ }^{\circ} \mathrm{C}$ and $12.6{ }^{\circ} \mathrm{C}$, respectively. The area is characterized by a bi-modal rainfall pattern ranging from $500-850 \mathrm{~mm}$, with the long rainy season extending from June to September [5].

The soils of the rift valley region are largely volcanic in origin [17], with $\mathrm{pH}$ ranging from slightly acidic to very alkaline [18]. The major field crops grown in the region are teff, barley, maize, lentils, faba bean, chickpea, and field pea. However, vegetable production is the most intensively practised activity in the agricultural production system of the area due to proximity to lucrative local markets in the capital Addis Ababa and Adama town. This marketing opportunity and high demand for the crop motivates farmers to produce vegetables in three cycles within the same year, but a two-cycle production is the most common one. The most important vegetables grown under irrigation in the region include snap beans, tomato, onion, cabbage, and broccoli [19].

\subsection{Sampling and Data Collection}

The primary data collection covered four districts in the Central Rift Valley Region of Ethiopia in eastern Shewa and Arsi Zones of the Oromia Regional State. Three districts are from eastern Shewa (Adama, Dugda Bora, and Adamitulu-Jiddokombolcha) whereas one district, namely, Merti, is from Arsi zone of the Regional State.

A two-stage sampling was employed to select onion producing districts, peasant associations (PAs) and households targeted by the study. A peasant association is the smallest unit of administration in rural Ethiopia, comprising hundreds of farm households. The districts, each of which comprises a number of peasant associations, were purposefully selected based on onion production potential. Similarly, eight peasant associations (PAs) were purposively selected from the whole study districts using a probability proportionate to the size of onion producing PAs in the district. Selection of the PAs in the districts was based on availability of year-round irrigation water potential. Similarly, from a whole list, names of household heads in each peasant association were selected through a systematic random sampling technique based on a probability proportionate to the size of onion producing peasant association. Hence, two PAs from Dugda Bora district (24 households), three PAs from Adamitulu-Jiddokombolcha district (66 households), two PAs from Adama district (29 households) and one PA from Merti district (9 households) were selected. Thus, a total of 128 households were used for the primary data collection in the study area based on the degree of heterogeneity of the population, time and resource availability. Moreover, for the purpose of having the right output from the survey work, collection of qualitative information was managed through focus-group discussions. The focus-group discussions were comprised three groups, each having six participants per district. Finally, primary data were supplemented with secondary data to ensure adequacy and reliability of the information gathered.

Both structured and semi-structured questionnaires were used as an instrument for the data collection. The questionnaires were reviewed and pre-tested, which helped further adjustment to solicit for desired responses. Data were collected using a formal survey technique through conducting interviews with household members, primarily 
shouldering the responsibility for production and management of onion. The data collection was carried out in 2011. Agricultural development agents within the districts and professionals from Ethiopian Institute of Agricultural Research, namely, Melkassa Agricultural Research Centre participated in the administration and collection of the questionnaires.

\subsection{Statistical Analysis}

Descriptive statistics, namely, mean, frequency distribution, and percentages were employed to analyse the data. The chi-square and t-test were employed using SPSS software version 18. Preliminary analysis of the data showed that there is no significant difference between the four districts. Thus, most of the statistical analysis was based on combined values of each variable from the four districts. Index ranking was calculated based on the formula: Index $=$ sum of $\left(6 \mathrm{x}\right.$ No. of respondents ranked $1^{\text {st }}+5 \mathrm{x}$ No. of respondents ranked $2^{\text {nd }}+4 \times$ No. of respondents ranked $3^{\text {rd }}+$ $3 \times$ No. of respondents ranked $4^{\text {th }}+2 \times$ No. of respondents ranked $5^{\text {th }}+1 \times$ No. of respondents ranked $6^{\text {th }}$ ) for each constraint divided by sum of $(6 \times$ total No. of respondent ranked $1^{\text {st }}+5 \mathrm{x}$ total No. of respondent ranked $2^{\text {nd }}+4 \times$ total No. of respondent ranked $3^{\text {rd }}+3 \times$ total No. of respondent ranked $4^{\text {th }}+2 x$ total No. of respondents ranked $5^{\text {th }}+1 x$ total No. of respondents ranked $6^{\text {th }}$ ) for all constraints mentioned [20].



Figure. 1. Location Map of the study area

\section{Results and Discussion}

\subsection{Demographic Characteristics and Fertilizer Management}

Age group, sex, household size, and educational status of household heads are shown in Table 1. The majority of the household heads directly involved in onion production were male $(89.1 \%)$. Similar findings on vegetable production were reported from previous studies in Ethiopia [21] and Cameroon [22]. This could be due to the labour demanding nature of the crop for different activities during production and the relatively limited freedom of women in Ethiopian culture to mobilize resources and participate in different farming activities in their villages as heads. It is, therefore, important to encourage involvement of women in vegetable farming with men to synergistically attain the goals of widespread efforts that are underway in the country to attain household and national food security.

The average age of the respondents was 36 years with most households $(97.7 \%)$ in the age category of 15-64 years. The study result indicated that onion production in the study area is mainly carried out by the active age group of the society. This might be due to government's positive policy in creating job opportunities for the youth and labour demanding nature of the crop. This is in line with the findings of [22] and [23], who reported that most vegetable farmers were in the active age group.

Diverse households educational status was observed, with the majority $(71.9 \%)$ being either illiterate or without any formal education. This result in is in contrast to the reports of [24] and [23], who, in peri-urban vegetable farms of Botswana, and Ghana, respectively, found that most vegetable farmers were literate. This lower literacy level of 
vegetable farmers in the study area, coupled with the poor extension services, in the region may have a negative impact on the overall soil fertility and postharvest management practices in onion production.

Table 1: Demographic characteristics of the sample households

\begin{tabular}{|c|c|}
\hline Variable & $\mathrm{N}=128$ \\
\hline \multicolumn{2}{|l|}{ Sex } \\
\hline Male(\%) & 89.1 \\
\hline Female(\%) & 10.9 \\
\hline \multicolumn{2}{|l|}{ Age of household head } \\
\hline Average & 35.95 \\
\hline Minimum & 18.00 \\
\hline Maximum & 67.00 \\
\hline SD & 11.54 \\
\hline \multicolumn{2}{|l|}{ Age category } \\
\hline $15-64$ years $(\%)$ & 97.7 \\
\hline$>64$ years & 2.3 \\
\hline \multicolumn{2}{|l|}{ Educational level } \\
\hline Illiterate (\%) & 21.1 \\
\hline Able to read and write (\%) & 50.8 \\
\hline $6^{\text {th }}$ grade and less $(\%)$ & 23.4 \\
\hline $7^{\text {th }}-12^{\text {th }}$ grade $(\%)$ & 3.9 \\
\hline Above $12^{\text {th }}$ grade $(\%)$ & 0.8 \\
\hline \multicolumn{2}{|l|}{ Family size } \\
\hline Average & 5.88 \\
\hline SD & 3.32 \\
\hline
\end{tabular}

Note: $\mathrm{SD}=$ Standard deviation

\subsection{Methods of Maintaining Soil Fertility in Onion Production}

Methods used for management of soil fertility in onion production in the study area include application of inorganic fertilizers such as urea and DAP (Diammonium phosphate), farmyard manure, and compost as well as crop rotation. The study revealed that all households use inorganic fertilizers and crop rotation to maintain soil fertility (Table 2). Similar findings have been reported by [25] in central Ethiopia, where application of inorganic fertilizer, compost, and farmyard manure is commonly practised in soil fertility management. The authors further indicated that the percentage of onion growers using farmyard manure, compost, and residue together in the study area is as low as $20.3 \%$. In contrast, the use of fallowing for soil fertility management was limited with only $4.8 \%$ (Table 2 ). Contrary to this report, however, [26] reported that about two-thirds of farmers in Ethiopia use fallowing for maize production. According to the interview of individual famers and focus group discussions, the limited use of fallowing was mainly due to small landholdings, which is directly related to high population growth that leads to land fragmentation and uninterrupted cultivation of the land that causes soil nutrient depletion and mining.

Table 2: Methods used for maintaining soil fertility in onion production

\begin{tabular}{lll}
\hline $\begin{array}{l}\text { Ways of maintaining soil } \\
\text { fertility }\end{array}$ & $\mathbf{N}$ & $\begin{array}{l}\text { Per cent of household } \\
(\%)\end{array}$ \\
\hline $\begin{array}{l}\text { Chemical } \\
\text { fertilizer[(Diammonium } \\
\text { phosphate(DAP) \& urea) }\end{array}$ & 128 & 100 \\
$\begin{array}{l}\text { Application of Farmyard } \\
\text { manure(FYM) }\end{array}$ & 14 & 10.9 \\
$\begin{array}{l}\text { Application of compost } \\
\text { Crop rotation }\end{array}$ & 7 & 5.5 \\
$\begin{array}{l}\text { Fallowing } \\
\text { Residue management }\end{array}$ & 128 & 100 \\
$\begin{array}{l}\text { Total number of sampled } \\
\text { households }\end{array}$ & 5 & 4.8 \\
\hline
\end{tabular}

Note: $\mathrm{N}=83$ for fallowing practice

\subsubsection{Use of DAP and Urea}

All sampled households used DAP and urea for onion production (Tables 2 and 3 ). The use of inorganic fertilizers by all sample households shows the importance of applying nutrients to production of the crop in the study area. In line with this finding, [27] reported that market-oriented vegetable production in Uganda cannot be realised without application of mineral fertilizers. In accord with the findings of this study, in the mid-altitude of western Ethiopia, more than $80 \%$ of the farmers use inorganic fertilizers for crop production [26, 25]. Accordingly, [28] indicated that DAP and urea were the sole nutrient sources used by farmers in Ethiopia as the soils of the country are severely deficient in plant-available nitrogen and phosphorus.

Households on average applied $298.8 \mathrm{~kg} \mathrm{ha}^{-1}$ urea and $299.21 \mathrm{~kg} \mathrm{ha}^{-1}$ DAP, respectively, in one growing season for vegetable production (Table 3 ). The amount ranged from $100-700 \mathrm{~kg} \mathrm{ha}^{-1}$ urea and 50-600 $\mathrm{kg} \mathrm{ha}^{-1} \mathrm{DAP}$. In general, the findings of this study revealed that onion growers in the study area applied higher doses of DAP and urea than the blanket recommended amount in the region, which is $200 \mathrm{~kg}$ $\mathrm{ha}^{-1}$ DAP and $150 \mathrm{~kg} \mathrm{ha}^{-1}$ urea. Besides, the analysis of variance showed a non-significant difference $(P \leq 0.05)$ in the amount of urea and DAP used among the study districts. In line with the findings of this study, excessively high fertilizer application in vegetable production was reported by [29]. Similarly, application of fertilizers in amounts that exceeded crop requirements of five-fold was reported for the Beijing area in China [30]. Moreover, [31] reported application of higher rates of mineral fertilizers for vegetable production in eastern Ethiopia. The absence of 
significant differences in the amounts of DAP and urea used by farmers in the study districts might be attributed to the similarity of the onion-growing farmers in educational status and other socio-economic conditions.

The high consumption rate of mineral fertilizers in the region could possibly be due to favourable government policies in increasing access of farmers to agricultural inputs to increase productivity, farmers' expectations of benefiting from increased use of mineral fertilizers as well as the use of flood irrigation system which often leads to inefficient use of nutrients owing to loss through leaching and run-off of the applied fertilizers. Besides, during the focus group discussions, farmers noted that their farm lands are relatively poor in fertility and therefore need to be fertilised with ample amounts of fertilizers.

Table 3: Reported amount of fertilizer applied in the study area

\begin{tabular}{|c|c|c|c|c|c|c|c|}
\hline \multicolumn{8}{|c|}{ Amount of urea $\left(\mathrm{kg} \mathrm{ha}^{-1}\right)$} \\
\hline District & $\mathrm{N}$ & $\%$ & Mean \pm SD & Minimum & Maximum & F-test & p-value \\
\hline Adama & 29 & 22.6 & $282.75 \pm 125.5$ & 100 & 600 & & \\
\hline Adamitulu-Jiddokombolcha & 66 & 51.6 & $320.9 \pm 124.5$ & 150 & 700 & & \\
\hline Dugda Bora & 24 & 18.8 & $281.25 \pm 117.7$ & 100 & 500 & & \\
\hline Merti & 9 & 7 & $233.3 \pm 70.7$ & 200 & 400 & & \\
\hline Total & 128 & 100 & $298.8 \pm 131.8$ & 100 & 700 & $1.671 \mathrm{NS}$ & 0.177 \\
\hline \multicolumn{8}{|c|}{ Amount of DAP $\left(\mathrm{kg} \mathrm{ha}^{-1}\right)$} \\
\hline Adama & 29 & 22.6 & $282.75 \pm 145.9$ & 100 & 600 & & \\
\hline Adamitulu-Jiddokombolcha & 66 & 51.6 & $294.69 \pm 121.5$ & 100 & 600 & & \\
\hline Dugda Bora & 24 & 18.8 & $302.08 \pm 117.4$ & 50 & 450 & & \\
\hline Merti & 9 & 7 & $377.77 \pm 100.3$ & 150 & 450 & & \\
\hline Total & 128 & 100 & $299.21 \pm 126.1$ & 50 & 600 & $1.373 \mathrm{NS}$ & 0.254 \\
\hline \multicolumn{8}{|c|}{ Amount of FYM and Compost } \\
\hline $\operatorname{FYM}\left(\mathrm{t} \mathrm{ha}^{-1}\right)$ & 14 & 10.9 & $1.71 \pm 1.36$ & & & & \\
\hline Compost $\left(\mathrm{t} \mathrm{ha}^{-1}\right)$ & 7 & 5.5 & $1.56 \pm 1.61$ & & & & \\
\hline
\end{tabular}

Note: $\mathrm{N}=$ number of respondents, $\mathrm{SD}=$ Standard deviation, $\mathrm{NS}=$ Non significant

Table 4: Method and timing of applying inorganic fertilizer

\begin{tabular}{lll}
\hline Timing for urea application & N & Per cent \\
\hline $\begin{array}{l}\text { Top dressing (split) } \\
\text { Basal dressing (once before }\end{array}$ & 114 & 89.1 \\
$\begin{array}{l}\text { planting) } \\
\text { Basal dressing (once at }\end{array}$ & 9 & 3.9 \\
planting) & 128 & 7.0 \\
Total & & 100 \\
$\begin{array}{l}\text { Timing for DAP application } \\
\text { Basal dressing (once before }\end{array}$ & 4 & \\
planting) & & 3.1 \\
Basal dressing (once at & 97 & 75.8 \\
planting) & 27 & 21.1 \\
Top dressing (split application) & 128 & 100. \\
Total & & \\
Method of application (DAP + & 4 & 3.1 \\
Urea) & 124 & 96.9 \\
Broadcast & 0 & 0.0 \\
Band & 128 & 100 \\
Other & & \\
Total & &
\end{tabular}

Note: $\mathrm{N}=$ Number of respondents

\subsubsection{Timing and Methods of Applying DAP and Urea}

Banding was the most common (96.9\%) method of applying urea and DAP fertilizers whilst broadcasting was less commonly used (3.1\%) (Table 4). Split application of urea was practised by most $(89.1 \%)$ of the growers during planting and weeding. DAP was applied only once at planting by the majority (75.8\%) of the households (Table 4). Band placement of fertilizer minimizes soil contact, reduces nutrient tie-up, and often results in increased fertilizer use efficiency [32]. Accordingly, [33] in Nigeria reported that band application of $\mathrm{P}$ fertilizer was found to be the most effective method in onion production.

\subsubsection{Use and Management Practices for Farmyard Manure and Compost}

In contrast to the use of the inorganic fertilizers, the use of farmyard manure and compost was very low, accounting only for $10.9 \%$ and $5.5 \%$, respectively (Table 2). Moreover, the average amounts of the organic materials used were very small with $1.7 \mathrm{t} \mathrm{ha}^{-1}$ for farmyard manure and $1.56 \mathrm{t} \mathrm{ha}^{-1}$ for compost (Table 3).

Supporting to these findings, [34] indicated that the use of manure is extremely low for soil fertility maintenance in 
Ethiopia. Participants in the focus group discussions alsoindicated that the bulky nature of organic manures for transport and application, limited availability of livestock manure and composting material, as well as poor knowledge and extension services were among the main causes for the use of small amounts of farmyard manure and compost in the area. In conformity, [26] reported a low supply and fewer users of organic fertilizer in Ethiopian lowlands. This was clearly observed in the findings of this study that all farmyard manure and compost users were the ones cultivating onions on their own landholdings rather than on rented land (Table 5). No land renters applied organic fertilizers. This is attributed to the fact application of manure is a long-term investment in soil fertility management for crop production and renters may have no guarantees whatsoever for the use of the rented land in the coming seasons. In line with this finding, insecure and crumbling tenure arrangements also contributed to declining soil fertility in Niger, where secure land, accounts for 90 percent of manured fields [35].

Table 5: Relationship between Farmyard manure (FYM) and compost use with type of land cultivated

\begin{tabular}{|c|c|c|c|c|c|c|c|c|c|}
\hline & \multicolumn{9}{|c|}{ FYM use } \\
\hline & Yes & & No & & Total & & $\mathrm{X}^{2}$ & p-value & Cramer's V \\
\hline Type of land & $\mathrm{N}$ & $\%$ & $\mathrm{~N}$ & $\%$ & $\mathrm{~N}$ & $\%$ & & & \\
\hline Own land & 14 & 100 & 70 & 61.4 & 84 & 64.8 & & & \\
\hline rented & 0 & 0 & 44 & 38.6 & 44 & 35.2 & & & \\
\hline \multirow[t]{3}{*}{ Total } & 14 & 100 & 114 & 100 & 128 & 100 & $5.411 * *$ & 0.020 & 0.206 \\
\hline & \multicolumn{9}{|c|}{ Compost use } \\
\hline & Yes & & No & & Total & & & & \\
\hline Type of land & $\mathrm{N}$ & $\%$ & $\mathrm{~N}$ & $\%$ & $\mathrm{~N}$ & $\%$ & & & \\
\hline Own land & 7 & 100 & 77 & 62.8 & 84 & 64.8 & & & \\
\hline rented & 0 & 0 & 44 & 37.2 & 44 & 35.2 & & & \\
\hline Total & 7 & 100 & 121 & 100 & 128 & 100 & $4.015 * *$ & 0.045 & 0.177 \\
\hline
\end{tabular}

Note: $* *=$ significant at 0.01 significance level

All farmyard manure and compost users for onion production in the study area were found to be the ones owning their own land and cattle (Tables 5 and 6). A chi-square statistic $(\chi 2=5.411, \mathrm{p}=0.020)$, revealed the presence of significant differences at $1 \%$ significance level in the use of farmyard manure between those cultivating their own land and those cultivating rented land. Similarly, significant differences $(\chi 2=4.015, \mathrm{p}=0.045)$ at $1 \%$ level of significance were obtained between those cultivating their own land and those cultivating rented land for onion production in the use of compost (Table 5). In Ethiopia, the pace of adopting application of organic manures and water harvesting technology was often determined by the feelings and attitudes farmers have on the ownership of the land they cultivate [36]. Similarly, [38] indicated that land tenure insecurity is one of the root causes for physical and biological soil degradation in Africa.

The average livestock holding per household was 2.82 Tropical Livestock Unit (TLU) (Table 6). The major livestock reared by households in the study area were cattle, sheep, goats, horses, donkeys, mules, and poultry. An independent sample t-test revealed a significant mean difference $(\mathrm{t}=11.13)$ at less than $1 \%$ significance level between livestock ownership and the use of farmyard manure, where farmyard manure users were found to possess more Tropical Livestock Unit (TLU) than non-users (Table 6). Moreover, the bivariate correlation $(\mathrm{r}=0.701 * * *)$ indicated the presence of a positive and strong relationship between livestock ownership and the use of farmyard manure (Table 6). In line with the findings of this study, many authors $[38,26]$ reported a strong association between livestock owners and the use of organic fertilizers in Ethiopia and semi-arid areas of Africa. Reports indicated that application of farmyard manure combined with inorganic fertilizers led to higher onion bulb yields and economic benefits in Ethiopia [39] and in vegetable production in Kenya [40], compared to the lone application of each fertiliser.

Table 6: Relationship between livestock holding in (Tropical livestock unit) and use of farmyard manure and compost

\begin{tabular}{clllllll}
\hline TLU & FYM use & $\mathbf{N}$ & Mean & SD & t-value & p-value & r \\
\hline Yes & 14 & 4.2 & 2.5 & & & \\
No & 114 & 1.6 & 1.42 & & & \\
Total & 128 & 2.82 & 2.21 & $11.127^{* * *}$ & 0.000 & $0.701^{* * *}$ \\
Compost use & & & & & \\
Yes & 7 & 3.2 & 2.8 & & & \\
No & 121 & 2.46 & 2.22 & & & -0.062 \\
\hline Total & 128 & 2.82 & 2.21 & $0.759 \mathrm{Ns}$ & 0.449 & \\
\hline
\end{tabular}

Note: $\mathrm{SD}=$ standard deviation; where $\mathrm{N}=$ Number of respondents 
Table 7: Distribution of households with storage, timing and method of farmyard manure and compost application

\begin{tabular}{lll}
\hline Variable & N & Per cent \\
\hline $\begin{array}{l}\text { Time(manure \& compost) } \\
\text { once (at time of land }\end{array}$ & $14(7)$ & 100 \\
preparation) & 0 & 0.0 \\
$\quad$ once at planting & 0 & 0.0 \\
other & $14(7)$ & 100 \\
$\quad$ total & $14(7)$ & 100 \\
Method (manure and compost) & $0(0)$ & 0.0 \\
broad casting & $14(7)$ & 100 \\
other & & \\
total & 13 & 93.0 \\
Manure storage & 1 & 7.0 \\
open field & 14 & 100 \\
protected & & 0.0 \\
total & 7 & 100 \\
Compost storage & 0 & \\
compost pit & 7 & \\
other & & \\
total & & \\
\hline
\end{tabular}

Note: Number in parenthesis $=$ number of compost users; where, $\mathrm{N}=$ number of respondents

\subsubsection{Storage, Timing, and Method of Application}

Most households applied farmyard manure and compost once before planting (basal) at the time of land preparation using the broadcast method. Open field storage was the most common method of storing farmyard manures which accounted for $93 \%$ of the households applying farmyard manure (Table 7). In conformity with these findings, [41] reported that over $60 \%$ of farmers stored farmyard manure in the open, leading to significant losses in nutrients. This indicates the presence of a huge loss of nutrients from farmyard manures due to volatilization and leaching of nutrients, which may lead to poor quality organic material to be used as a fertilizer source. Similarly, [41] indicated a significant loss of nutrients especially nitrogen from organic manures stored in the open due to leaching during the rains or even denitrification when the sheds become soggy and anaerobic conditions prevail.

\subsection{Onion Bulb Yield and Postharvest Handling Practices}

The yield of onion in the study area is shown in Table 8.The average yield ranged from 10-35 $\mathrm{t} \mathrm{ha}^{-1}$ within the districts having an overall average of $23.02 \mathrm{t} \mathrm{ha}^{-1}$. This average productivity obtained in the current study is much higher than the national average productivity of $10.75 \mathrm{t}$ $\mathrm{ha}^{-1}[8]$. The increased productivity of onion might be due to the greater focus and encouragement given by Ethiopian government in vegetable production in particular and agricultural production in general, which may have contributed to the increased marketing and input supply. Availability of improved seed, nursery management, and other agronomic management practices may be some of the factors that are promoting increased productivity of the crop. However, more has to be done to further improve the yield of onion on farmers' fields since the productivity is still much lower than the productivity from research fields, which averages 30-35 $\mathrm{tha}^{-1}[2]$. Therefore, technical training and extension services on improved crop husbandry have to be further strengthened to enhance productivity.

Table 8: Reported bulb yield $\left(t \mathrm{~h}^{-1}\right)$, postharvest handling and marketing of onions in the study area

\begin{tabular}{|c|c|c|c|c|c|c|c|}
\hline District & $\mathbf{N}$ & $\%$ & Mean \pm SD & Min & Max & F-test & p-value \\
\hline Adama & 29 & 22.7 & $22.3 \pm 6.7$ & 14 & 35 & & \\
\hline Adamitulu-Jiddokombolcha & 66 & 51.6 & $23.8 \pm 4.8$ & 14 & 31 & & \\
\hline Dugda Bora & 24 & 18.7 & $22.9 \pm 5.8$ & 10 & 32 & & \\
\hline Merti & 9 & 7 & $20 \pm 3.9$ & 16 & 26 & & \\
\hline Total & 128 & 100 & $23.02 \pm 5.5$ & & & $1.558 \mathrm{NS}$ & 0.203 \\
\hline \multicolumn{8}{|l|}{ Store onions } \\
\hline Yes & 0 & 0.0 & & & & & \\
\hline No & 128 & 100 & & & & & \\
\hline Total & 128 & 100 & & & & & \\
\hline \multicolumn{8}{|l|}{ Apply post-harvest treatment } \\
\hline Yes & 0 & 0.0 & & & & & \\
\hline No & 128 & 100 & & & & & \\
\hline Total & 128 & 100 & & & & & \\
\hline \multicolumn{8}{|l|}{ Sell of produce (Marketing) } \\
\hline $\begin{array}{l}\text { Directly to wholesalers on farm through } \\
\text { special dealers }\end{array}$ & 121 & 94.5 & & & & & \\
\hline $\begin{array}{l}\text { Directly to distributors on the market of } \\
\text { nearby towns }\end{array}$ & 2 & 1.6 & & & & & \\
\hline $\begin{array}{l}\text { To nearby towns market and selling to } \\
\text { consumers }\end{array}$ & 5 & 3.9 & & & & & \\
\hline Total & 128 & 100 & & & & & \\
\hline
\end{tabular}

Note: $\mathrm{N}=$ number of respondents, $\mathrm{SD}=$ Standard deviation, $\mathrm{Min}=$ minimum, $\mathrm{Max}=$ Maximum, $\mathrm{NS}=$ non-significant 
With respect to postharvest handling, all sampled households in the study area do not store and use any post-harvest treatment options to improve the marketability and postharvest shelf life of onions (Table 8). In line with this finding, [42] and [21] reported that farmers in Ethiopia and India do not cure/treat as well as store onions; hence, producers often sale their produces in the market immediately after harvesting to avoid postharvest losses and handling costs. This shows that farmers are not getting deserved prices and incomes as they are solely dependent on the prevailing market "pseudo-prices" at the time of harvest, which are mostly fixed by brokers.

\subsection{Constraints in Soil Nutrient Management and Post-harvest Handling Practices for Onion Production}

\subsubsection{Constraints in the Use of DAP and Urea}

Factors associated with the use of DAP and urea that constrain onion production were high cost, low accessibility, and poor knowledge on fertilizer management (Table 9). In Ethiopia, studies by [31] revealed that the practicability of using organic mineral fertilizers by smallholder farmers is constrained by high costs. Similarly, in India, high costs of inorganic fertilizers were identified as the major factors constraining onion production $[43,45]$. Besides, absence of access to credit has been a great challenge in the use of the required amounts of inorganic fertilizers (Table 9). Corroborating this suggestion, previous reports revealed that fertilizer use in onion production in Ethiopia and India is

constrained by lack of access to credit facilities [44, 45].

The supply side of inorganic fertilizers to farmers has been encouraging but lack of accessibility was the major problem (Table 9). Several authors [26, 41, 24] indicated the limited accessibility of fertilizers in Africa greatly undermines vegetable production in particular and agricultural production in general.

Poor knowledge on the use of inorganic fertilizers especially on applying the right amounts at the appropriate time and lack of appropriate agricultural extension services were the other major problems pinpointed by farmers in the individual interviews and focus group discussions (Table 9). Several related findings have been reported in Ethiopia [26] and in different parts of Africa and Asia [42, 43, and 45] for onion and cereal crops production.

Table 9: Constraints for the use of DAP and Urea

\begin{tabular}{|c|c|c|c|c|c|c|c|c|}
\hline \multicolumn{9}{|c|}{ Ranking } \\
\hline Constraints & $1^{\text {st }}$ & $2^{\text {nd }}$ & $3^{\text {rd }}$ & $4^{\text {th }}$ & $5^{\text {th }}$ & $6^{\text {th }}$ & Index & Rank \\
\hline High cost & 57 & 22 & 23 & 3 & 0 & 0 & 0.20860 & 1 \\
\hline Availability & 22 & 27 & 21 & 25 & 26 & 11 & 0.18445 & 5 \\
\hline Accessibility & 16 & 29 & 25 & 33 & 37 & 14 & 0.19917 & 2 \\
\hline Absence of access to credit & 20 & 25 & 18 & 30 & 34 & 16 & 0.18521 & 4 \\
\hline $\begin{array}{l}\text { Poor knowledge \& extension } \\
\text { service }\end{array}$ & 11 & 24 & 39 & 32 & 29 & 16 & 0.19313 & 3 \\
\hline $\begin{array}{l}\text { Other(shortage of moisture \& } \\
\text { labour) }\end{array}$ & 0 & 0 & 0 & 3 & 0 & 69 & 0.02942 & 6 \\
\hline Total & 126 & 127 & 126 & 126 & 126 & 126 & & \\
\hline
\end{tabular}

\subsubsection{Constraints in the Use of Farmyard Manure and Compost}

Horticultural crops respond well to the use of organic manures [46]. Despite a mixed crop-livestock farming system in the study area, there is limited use of manures. Farmers in the area singled out that bulkiness to transport and apply the manures and limited availability of composting materials, coupled with absence of landownership (rented land for onion production) as the major bottlenecks hampering the use of organic manures (Tables $10 \& 11$ ). Labour shortage in preparing compost pits and related activities was raised as one of the major factor constraining the use of compost by farmers in the study area (Tables $10 \& 11$ ). Similarly, bulkiness and difficulty of transporting and limited availability of organic manure were reported to have constrained vegetable and crop production in Ghana and South Africa [23, 41].

Absence of effective extension services has been raised by individual farmers and focus group participants as another major factor hampering the use of or organic manures

in vegetable production the study area (Tables $10 \& 11$ ). As a result, substandard storage facilities and reckless handling of organic manures is the extra problems for the decline in the quality of manure. Consistent with the results of this study, it was reported that weak extension services on appropriate timing, placement, and dosing fertilizers by farmers severely affected vegetable production in Kenya and Ghana [47, 23].

Land ownership has been cited as a fourth ranking problem hindering the use of organic manure in onion production. Research findings suggest that farmers' decisions on adopting new technologies are dependent mainly on the fertility status of the land, access to irrigation, and profitability [48]. Similarly, insecure and crumbling land tenure arrangements were reported to have contributed to declining soil fertility in Niger, where secured land 
accounts for 90 per cent of the manured fields [35]. Similarly, [49] reported that, in Ghana, sharecroppers put enormous pressure on soil fertility to realise immediate high yields in order to pay land rents.

Table 10: Constraints in the use of farmyard manure

\begin{tabular}{|c|c|c|c|c|c|c|c|c|}
\hline \multicolumn{9}{|c|}{ Ranking } \\
\hline Constraint & $1^{\text {st }}$ & $2^{\text {nd }}$ & $3^{\text {rd }}$ & $4^{\text {th }}$ & $5^{\text {th }}$ & $6^{\text {th }}$ & Index & Rank \\
\hline Bulkiness for transport & 55 & 23 & 19 & 8 & 3 & 0 & 0.20816 & 1 \\
\hline Limited availability & 26 & 29 & 22 & 33 & 15 & 0 & 0.19569 & 2 \\
\hline Poor knowledge \& extension service & 19 & 21 & 36 & 30 & 31 & 2 & 0.19531 & 3 \\
\hline Burns the crop and spread weeds & 8 & 26 & 24 & 26 & 26 & 9 & 0.15602 & 5 \\
\hline Absence of own land/land ownership & 16 & 29 & 25 & 24 & 19 & 22 & 0.17869 & 4 \\
\hline Other (messy \& hard to handle, attract insects) & 0 & 0 & 0 & 6 & 32 & 93 & 0.06611 & 6 \\
\hline Total & 124 & 128 & 126 & 127 & 126 & 126 & & \\
\hline
\end{tabular}

Table 11: Constraints for compost use

\begin{tabular}{|c|c|c|c|c|c|c|c|c|}
\hline \multirow[b]{2}{*}{ Constraints } & \multicolumn{8}{|c|}{ Ranking } \\
\hline & $1^{\text {st }}$ & $2^{\text {nd }}$ & $3^{\text {rd }}$ & $4^{\text {th }}$ & $5^{\text {th }}$ & $6^{\text {th }}$ & Index & Rank \\
\hline Limited availability of composting materials & 33 & 28 & 21 & 13 & 7 & 0 & 0.19974 & 1 \\
\hline Bulkiness for transport & 23 & 18 & 20 & 15 & 14 & 17 & 0.16736 & 5 \\
\hline Poor knowledge \& extension service & 18 & 24 & 24 & 16 & 17 & 21 & 0.17956 & 3 \\
\hline Absence of own land/land ownership & 23 & 23 & 18 & 17 & 16 & 6 & 0.17409 & 4 \\
\hline Shortage of labour & 21 & 25 & 25 & 17 & 12 & 17 & 0.18629 & 2 \\
\hline Other (nutrient release, bad smell) & 0 & 0 & 12 & 22 & 34 & 39 & 0.09293 & 6 \\
\hline Total & 118 & 118 & 120 & 100 & 100 & 100 & & \\
\hline
\end{tabular}

\subsubsection{Constraints in Post-harvest Handling Practices}

Limited availability of storage facilities was the major factor that compelled producers to sell all their produce immediately after harvest, risking much lower prices than would be under normal market conditions (Table 12). In line with this finding, several researchers [50,3, and 31] reported that absence of storage facilities were the major constraints to the production and marketing of horticultural crops in Ethiopia and India.

The households strongly raised that poor knowledge and extension on postharvest handling and storage as the major bottleneck for the profitability of onion production and marketing in the area (Table 12). Besides, in the focus group discussions, it was stressed that the lack of knowledge and extension services on pre-harvest management practices for enhanced post-harvest quality and storability hinders effective implementation of onion bulb storage. The farmers further suggested that training be given on pre-harvest management to improve productivity of onion in the region. A similar finding was reported for India by [43].

Lack of access to credit has a great impact on establishing storage structures and facilities as well as guaranteeing regular cash flows (Table 12). Results consistent with the findings of this study were reported for India by [12]. Moreover, poor storage potential of existing onion varieties was identified as a barrier to applying post-harvest handling practices by the individual interviews and focus group discussions (Table 12).

Table 12: Constraints on the use of postharvest handling practices as prioritized by the sample households

\begin{tabular}{lllllllll}
\hline \multicolumn{1}{l}{ Ranking } & & & & \\
\hline Constraints & $\mathbf{1}^{\text {st }}$ & $\mathbf{2}^{\text {nd }}$ & $\mathbf{3}^{\text {rd }}$ & $\mathbf{4}^{\text {th }}$ & $\mathbf{5}^{\text {th }}$ & $\mathbf{6}^{\text {th }}$ & Index & Rank \\
Unavailability of storage facilities & 27 & 28 & 26 & 13 & 8 & 0 & 0.18043 & 2 \\
Limited regular cash flow & 29 & 30 & 23 & 17 & 7 & 3 & 0.18943 & 1 \\
Poor knowledge and extension services & 19 & 23 & 29 & 21 & 16 & 8 & 0.17534 & 3 \\
Absence of good storing varieties & 19 & 17 & 19 & 28 & 20 & 13 & 0.16125 & 5 \\
Lack of access to credit service & 32 & 22 & 19 & 15 & 5 & 4 & 0.17103 & 4 \\
Other & 1 & 7 & 11 & 26 & 44 & 62 & 0.12250 & 6 \\
Total & 127 & 127 & 127 & 120 & 100 & 90 & &
\end{tabular}




\section{Conclusion and Recommendation}

This study has revealed that onion producing smallholder farmers in the Rift Valley Region of Ethiopia apply higher amounts of inorganic $\mathrm{N}$ and $\mathrm{P}$ fertilizers than the amounts prescribed by the research system for producing the crop. However, the results also showed that the farmers apply low amounts of organic manures such as farmyard manure and compost to produce the crop. This may exacerbate deterioration of soil quality and make production of the crop unsustainable in the long term due to depleting of organic matter. In addition, farmers practice little post-harvest management and offer their produce for sale as soon as they harvest, risking lower prices. The major problems constraining proper soil nutrient management and postharvest handling practices in onion production in the study area include high cost of inorganic fertilizers with limited accessibility, bulkiness to transport and apply manures, limited availability of composting materials, poor knowledge and extension services, and absence of access to credit. Therefore, to enhance onion production and productivity in the area, it is vital to increase accessibility of smallholder farmers to inorganic fertilizers at affordable prices, and create awareness on integrated use of optimum rates of inorganic fertilizers and organic manures. Besides, introducing low-cost storage structures, making growers aware of the benefits accruing from post-harvest handling practices, and improving access to credit facilities through organizing growers in to formal onion producing cooperatives is recommended. Future research on the crop in the study area should focus on studies geared towards formulating appropriate rates of inorganic and organic fertilizers for optimum yield and quality of the crop. In addition, research will have to look into affordable post-harvest practices and storage methods that may prolong shelf-life of the crop to stabilize market prices and maximize incomes of farmers.

\section{Acknowledgements}

Thanks are due to the Ethiopian Ministry of Education, which provided the fund required to do this research. The authors would also like to thank the Office of Agriculture and Rural Development as well as that of Finance and Economic Development of the Oromia Regional State. Thanks are due to Adama, Dugda Bora, Adamitulu-Jiddokombolcha and Merti district Bureaus of Agriculture and Rural Development for facilitating the survey work. Haramaya University is also acknowledged for managing the finance allocated for the research.

\section{References}

[1] T.C. Ketter and W. M. Randle. Pungency Assessment in Onions. In: S. J. Karcher (Eds.). Tested studies for laboratory teaching. Proceedings of the $19^{\text {th }}$ Workshop/Conference of the Association for Biology Laboratory Education (ABLE), Volume 19. 1998.

[2] D. Lemma and A. Shemelis. Onion: Research results and experiences in dry bulb and seed production in Ethiopia. Vegetable crops improvement research, EARO, Melkassa Agricultural Research Centre. 39p. 2003.

[3] M. Fekadu and G.Dandena. Review of the status of vegetable crops production and marketing in Ethiopia. Uganda Journal of Agricultural Sciences 12(2): 26-30. 2006.

[4] F. Joosten, D. Boselie, W. Bekele and D. Lemma. Exporting fruit and vegetables from Ethiopia: Assessment of the development potentials and investment options in the export-oriented fruit and vegetable sector. Ethiopia-Netherlands horticulture partnership programme, a study commissioned by Ethiopian Horticultural Development Agency and Ethiopian Horticultural Producers' and Exporters' Association. pp51. 2011.

[5] H. Jansen, H. Hengsdijk, L. Dagnachew, A. Tenalem, P. Hellegers and P. Spliethoff. Land and water resources assesement in the Ethiopian central Rift valley. Project: ecosystems for water, food and economic development in the Ethiopian central rift-valley. Alterra-rapport 1587, Alterra, Wageningen. 2007.

[6] CSA (Central Statistical Authority). Ethiopia Agricultural, Sample Enumeration of ETFRUIT. Annual Report. 983/84-1997/98, 2002. Addis Ababa, Ethiopia.

[7] MOWR (Ministry of Water Resources). Awash River Basin Flood Control and Watershed Management Study Project, Phase-2 Summary Report, Vol-2 Annex-B, 2007. Addis Ababa, Ethiopia.

[8] CSA (Central Statistical Authority). Report on area and production of Private peasant holdings. Statistical Bulletin. Volume 4. 2010. Addis Ababa, Ethiopia.

[9] FAO (Food and Agricultural Organization of the United Nations), 2010. FAOSTAT data, 2010. www.FAO.org.

[10] F. Tadesse. Post-harvest losses of fruits and vegetables in horticultural state farms. Acta Hort. 270:261-270. 1991.

[11] AVRDC (Asian Vegetable Research and Development Centre). Global Horticulture Assessment. University of California Davis, $2005 . \quad 144 \quad$ p. http://pdf.usaid.gov/pdf_docs /PNADH769.pdf

[12] M. Choudhury. Recent Developments in Reducing Postharvest Losses in the Asia-Pacific Region. In: Rosa, S.R.(Eds.). Postharvest Management of Fruit and Vegetables in the Asia-Pacific Region. Reports of the APO seminar on Reduction of Postharvest Losses of Fruit and Vegetables held in India, 5-11 October 2004. Asian Productivity Organization and Food and Agriculture Organization of the United Nations, Rome, Italy. pp.15-22. 2006

[13] G. Peter, F. Graham and J.E. Orchard. Crop Post-Harvest: Science and Technology Volume 1: Principles and Practice. Blackwell Science Ltd, a Blackwell Publishing Company. Pp577. 2002

[14] E. Ouedrago, A. Mando and N.P. Zombre. Use of compost to improve properties and crop productivity under low input agricultural system in West Africa. Agriculture ecosystem 
and environment 84:259-266. 2001.

[15] C.S. Pathak, L.L. Ko, S.S. Black, S.J. Cherng and T.C. Wang. Genetic improvement of onion for the Tropics. Onion news letter for the tropics. 1996. 7: 12-15.

[16] I.R Gubb and M.S.H. Tavis. Onion preharvest and postharvest considerations. In: H.D. Rabinowitch, and L. Currah (Eds.). Allium Crop Science. CABI publishing, UK. 2002. pp. 237-250.

[17] M.J. Markin, T.J. Kingham, A.E. Waddams, C.J. Brichall and T. Tamene. Development prospects in the Southern Rift Valley, Ethiopia. Volume 2. Land Resource Division, Land Resource Study 21. 1975. Ministry of Overseas Development, Tolworth Tower, Surbiton, Surrey, England.

[18] F. Itanna. Sulphur distribution in five Ethiopian Rift Valley soils under Humid and Semi- Arid Climate. J. Arid Environ. (Article in Press). 2005.www.elsvier.com/locate/ jnlabr/yjare, pp16.

[19] J. Moti. Interlocked markets and intensity of input use in vegetable production: A case around Lake Ziway, Oromiya region, Ethiopia. 2002. MSc. Thesis, Wageningen University, Neitherlands

[20] Gebremeskel Gebretsadik, Getachew Animut and Frew Tegegne. Assessment of the Potential of Cactus pear(Opuntia ficus indica) as livestock feed in Northern Ethiopia. Livestock Research for Rural development, 25(02), 2013.

[21] A. Tadesse. Farmers' evaluation and adoption of improved onion production package in fogera district, south Gondar, Ethiopia. 2008. MSc Thesis, Haramaya University, Ethiopia.

[22] T. Emile, T.H. Ntangmo, T. Njine, M.A. Serve. Vegetable Production Systems of Swamp Zone in Urban Environment in West Cameroon: Case of Dschang City. Universal Journal of Environmental Research and Technology 2:2: 83-92. 2012.

[23] K. Agyarko and W.J. Adomako. Survey of the use of organic manure among vegetable farmers in selected districts in Ghana. Journal of Sustainable Development in Africa 9(4):1-15. 2007

[24] M. E. Madisa, Y. Assefa and M.Obopile. Assessment of Production Constraints, Crop and Pest Management Practices in Peri-Urban Vegetable Farms of Botswana. Egypt. Acad. J. biolog. Sci., 1(1): 1 - 11. 2010

[25] T. Agajie, D. Mesfin, K. Getu, K. Aemiro, A. Leyusew and M. Takele. Socio-Economic Assessment of Production and Utilization of Crop Residues in the Central Highlands. Efficient use of Crop Residues: Animal Feed Vs Conservation Agriculture. Research Project. Research Report 93, EIAR, Addis Ababa. 2011. pp.20-21

[26] B. Dereje, A. Girma, G. Abdissa and H. DeGroote. The determinants of fertilizer and manure use in maize production in western Oromiya, Ethiopia. Seventh Eastern and Southern Africa Regional Maize Conference, 11-15 February 2001. pp. 438-441.

[27] C. Ssekabembe, K. C. Bukenya and W. Nakyagaba. Traditional knowledge and practices in local vegetable production in central Uganda. In: African Crop Science Conference Proceedings, Vol. 6. 14-19, 2003, Uganda. 2003. pp. 14-19.
[28] Y. Takashi and A. Ayumi. Fertilizer Policies, Price, and Application in East Africa. National Graduate Institute for Policy Studies, 2010. 7-22-1 Roppongi, Minato-ku, Tokyo, Japan

[29] M. W. Stewart, W.D. Dibb, E.A. Johnston and J.T. Smyth The Contribution of commercial fertilizer nutrients to food production. Agronomy Journal 97:1-6. 2005.

[30] C. Qing, Z. Xiaosheng, Z. Hongyan, C. Peter, L. Xiaolin, H. Dieter and L. Hans-Peter. Evaluation of current fertilizer practice and soil fertility in vegetable production in the Beijing region. Nutrient Cycling in Agro ecosystems 00: 1-8. 2004.

[31] E. Bezabih, and H. Gebremedhin. Constraints and Opportunities of Horticulture Production and Marketing in Eastern Ethiopia. DCG Report No. 46, 2007. p105.

[32] C.B. Smith, K.T. Demchak and P.A. Ferretti. Fertilizer Placement Effects on Growth Responses and Nutrient Uptake of Sweet Corn, Snap beans, Tomatoes and Cabbage. Commun. Soil Sci. Plant Anal. 21(1\&2)107-123. 1990

[33] . P.K. Kwakye, and S.J. Wapastda. Phosphorus requirement of onion (Allium cepa L.) in the Sudan savanna zone of Nigeria. Ghana Jnl agric. Sci. 28·29. 53-59.1995.

[34] G. Zelleke, G. Agegnehu, D. Abera and S. Rashid. Fertilizer and Soil Fertility Potential in Ethiopia: Constraints and opportunities for enhancing the system. IFPRI working paper Soil Fertility Potential. 2010,42p.

[35] J. Hopkins, C.P. Berry, and P. Gruhn. Soil fertility management decisions: Evidence from Niger. 1995. Report to USAID BOA DAN- 4111-B- 00-9112-00.

[36] R. Senait. Decision making on manure use and fallowing as soil fertility maintenance techniques in the Northern Highlands of Ethiopia: The case of Ankober District. 1999. Paper to be submitted to An International Conference on: Contemporary Development Issues in Ethiopia, August 16-18, 2001, Western Michigan University Campus, USA.

[37] A. Bationo, A. Hartemink, O. Lungu, M. Naimi, P. Okoth, E. Smaling and L. Thiombiano. "African Soils: Their Productivity and Profitability of Fertilizer Use". Background Paper Prepared for the African Fertilizer Summit, 2006. Abuja, Nigeria

[38] . B. Charlotte and T. Cathryn. The Contribution of Soil and Water Conservation to Sustainable Livelihoods in Semi-arid areas of Sub-Saharan Africa. Journal of Agricultural Research and Extension Network. No 102. 2000.

[39] G. Fisseha. The effects of alternative sources of organic fertilizers in increasing the yield of onions (Allium Cepa L.). 1983. MSc Thesis, Addis Ababa University, Addis Ababa.

[40] F. Place, B.C. Barret, H.A. Freeman, J.J. Ramisch and B. Vanlauwe. Prospects for integrated soil fertility management using organic and inorganic inputs: Evidence from smallholder African agricultural systems. Food Policy 28 (2003): 365-378. 2003

[41] J. Odhiambo and N. Magandini. An assessment of the use of mineral and organic fertilizers by smallholder farmers in Vhembe district, Limpopo province, South Africa. African. Journal of Agricultural Research 3 (5):357-362. 2008.

[42] D. Shah. An economic evaluation of onion production and its 
marketing in Maharashtra. Indian J. Agric. Markt. 13(3): 11-20. 1999.

[43] G.K. Waman and P.S. Patil. Production, storage and marketing constraints faced by onion growers. Maharashtra J. Extn. Edu., 19: 104-108. 2000.

[44] G. Adugna. Analysis of fruit and vegetable market chains in Alamata, southern zone of Tigray: The case of onion, tomato and papaya. MSc Thesis, Haramaya University, Ethiopia. $2009,114 \mathrm{pp}$

[45] A.J. Barakade and T. Lokhande. A Study of Problems Faced by Onion Growers in Satara District of Maharashtra. International Referred Research Journal Vol-II (18):80-82. 2011.

[46] M.S. Islam. Use of Bioslurry as Organic Fertilizer in Bangladesh agriculture. International workshop on the use of bioslurry domestic biogas programmes, 27-28 September 2006, Bangkok, Thailand.
[47] J. F. Onim, P. Ochola, P. Fitzhugh and H. A. Oduor. Potential of goat manure as a valuable fertilizer for small-scale farmers In: Proceedings of the Eighth Small Ruminants Scientific Workshop. Small Ruminants Collaborative Research, ILRAD, Nairobi, Kenya. 1990. Pp.157-170

[48] S.K. Mukhopadhyay. Adapting household behaviour to agricultural technology in West Bengal, India: wage labor, fertility, and child schooling determinants. Econ. Devt Cult. Change 43 (1). 91-115.1994.

[49] G. Benneh. Toward sustainable agriculture in Sub-Saharan Africa: Issues and strategies. IFPRI Lecture Series No. 4. 1997. International Food Policy Research Institute, Washington, D.C.

[50] V.R. Kiresur and N. Ganeshkumar. Impact of regulation on vegetable marketing in Indian - A case study in Dharwad district of Karnataka state. Indian J. Agric. Markt., 2(1): 23-30. 1998. 